\title{
Incidence of Ectoparasites in Broiler Chicken in Meerut
}

\author{
Garima Kansal and Hridaya Shanker Singh \\ Molecular Taxonomy Laboratory, Department of Zoology, Ch. Charan Singh University, Meerut
}

\begin{abstract}
A study was conducted to observe the frequency and density of ectoparasites affecting Broiler chicken of Meerut region. In rural areas chicken form an integral part of village life \& have an important social value in some countries, they are considered as an important source of income besides providing a cheap source of protein to rural people however disease are among the important constraint in the expansion of this industry. In most areas, control of disease is either lacking, very minimal or unheard of. During the study in all 82 chicks were examined, out of which 58 were infected and 24 were uninfected. The percent of infection was found to be $70.73 \%$. Out of 58 infected birds, 31\%exhibited single infection, 44.82\% showed double infection and $24.13 \%$ were with triple infection. One of them was found infected with more than three ectoparasites. In all 10 different types of ectoparasites were found harboring broiler in Meerut. Parasite wise percent of infecton was found to be.Menacanthus stramineus 3\%, Menacanthus cornutus 14\%, Ligeurus lawrensis tropicalis 22\%, Goniocotes gallinae 15\%, G.dissimilis 8\%, Poultry mites(Ornithonyssus bursa and Dermanyssus gallinae)75\%, Fowl Tick(Argas persicus)50\%, Sticktight Flea(Echidnophaga gallinacean)4\%.Possible reasons are discussed in detail.
\end{abstract}

Key Words: Ectoparasites, Poultry, Broiler Chicken, Meerut.

\section{Introduction}

In India, poultry meat is estimated to represent almost $20 \%$ of all meat, with an expected $20 \%$ increase in production by the year 2012. India is the first largest producer of eggs and ninth largest of poultry meat in the world, producing 34 billion egg and about 600,00 tons of poultry meat. The low productivity is mainly due to high mortality, which is caused by mismanagement, diseases, lack of nutritional feeding and predators. Arthropods are important pests of poultry throughout the globe including India, especially where proper management practices are not implemented. Lice and mites are the most common pests of poultry, although the fowl tick and the stick tight may also cause serious problems. Thus, with a view to enrich our knowledge on the morphology and the taxonomy of ectoparasites of broiler chicken in Meerut, the present investigation was started, with the hope that finds will form a base line for future studies in this field.

Paper dealing with the economic effects of ectoparasitism on poultry birds have been reported by workers like Warren et al., (1948)[1]; Edgar and King (1950)[2]; Glees and Raun (1959)[3]; Stockdale and Raun (1960)[4]; Derylo (1968, 1974 and 1974)[5][6][7]; De Vaney (1976)[8]; Pavlovic et al., (1988 and 1989)[9][10]; Lehmann (1993)[11] and Islam et al., (1999)[12]. Information regarding the pathogenic involvement of avian lice has been provided by selected workers viz., Olitsky and Casal (1959)[13]; Eddie et al., (1962)[14]; Derylo (1969, 1970, 1972 and 1975)[15][16][17][18] and Derylo and Jarosz (1972)[19]. The capability of certain avian lice to reservoir and transmit the filarial worms has also been demonstrated by Pennington and Phelps (1969)[20]; Seager et al., (1976)[21]; Bartlett and Anderson (1987 and 1989)[22][23] and Cohen et al., (1991)[24].

Certain workers have provided very useful information on in vitro biology of poultry ectoparasites and their morphology and taxonomy Wilson (1934 and 1939)[25]26]; Arora and Chopra (1959)[27]; Stockdale and Raun (1965)[28]; Ahmad (1986)[29]; and Saxena et al.,(1991)[30]; and Surman et al., (1998)[31].Rafiq (2000)[32]; Singh et al., (2000)[33]; Kumar (2002)[34] and Goel et al., (2005)[35].

\section{Materials and Methods}

Ectoparasites were sampled by the examination of host's body. Live host, the broiler chicken can be examined in various ways. Ectoparasites can be picked off by parting the feathers by hand. Small vacuum cleaner has also been used for removing lice. Second method involves the anaesthetizing of parasites. This method allows the host to continue breathing normally while parasites on its body are anaesthetized. Another method used for removing ectoparasites from live bird is dust ruffling. Pyrethrum powder is the most popular insecticide used for this purpose. Silica Aerogel powder is another powder used for dust ruffling. For the present study, the visual examination of chicks was the only available option as most of the poultry birds examined belong to poultry keepers. During examination, bird's legs were tied with the help of assistant. Individual feather were manually deflected to observe the presence of lice. Dehydration procedure was carried out, following 
standard methods, Finally, specimens were mounted under the cover slip in Canada balsum or DPX. Photomicrographs of different ectoparasites, were taken with the help of Motic Research Microscope.

\section{Menacanthus stramineus}

\section{Observations}

It is commonly known as the Body louse or the "Large body louse". This large species of Menacanthus lives most of the time on the skin of chicken. The smaller ones are pale, but the yellowish white larger ones, which reach a length of nearly $1 / 8$ inch, appear brownish. It has relatively small, triangular head, simple and short antennae.

\section{Menacanthus cornutus}

Present study reveals that it not only infests the poultry birds but ranks higher in the order of abundance. This species must be capable of inflicting loss to the health and productivity of birds due to its haematophagus nature. Their role in reservoiring and transmitting infections agents deserves investigation.

\section{Menopon gallinae(Linne,1758)[36]}

This species commonly known as "Shaft louse" or "small body louse". It has been recorded from all over the world, on domestic fowl. Heavily infested fowl are frequently seen devoid of feathers on tibia hip region due to the damage by the louse and self preening. M.gallinae commonly been considerd the most injurious louse of chicken.

\section{Lipeurus lawrensis tropicali(Peters,1931)[37]}

This species commonly called as the "Tropical hen louse". This is normally found on feathers of head and neck and also frequently occurs on wing and tail feathers. This species is dark black in colour. The body markings are very conspicuous, forehead is larger with a minute angulations. It found on upper portions of the feathers and seldom goes to the skin.

\section{Goniocotes gallinae(De Geer,1778)[38]}

It is commonly known as the "Fluff louse" or "Lesser hump" as they occur in the fluff at the base of feathers of fowl. It commonly inhabits fluffy basal part of the feathers and is abundant on the down feathers of the cloacal region.

\section{Goniodes dissimilis(Denny,1842)[39]}

It is commonly called as the "Brown chicken louse" or "Golden brown chicken louse" or "chicken goniodes". It mainly occupies back feathers but also occurs on breast and abdomen. It has been recorded from all parts of the worlds but is of very rare occurrence.

\section{Poultry Mites}

They are of two types-

\subsection{Dermanyssus gallinae (Red Chicken Mite)}

The Chicken mites suck the blood from the birds at night and then hide in the cracks and crevices of the houses during the day.

\subsection{Ornithonyssus bursa(Tropical Fowl)}

The Tropical Fowl Mites suck blood from all different types of fowl and can live in the temperate regions of the world.

\section{Argas persicus}

The fowl Tick, also called the Blue Bug, injures poultry by blood feeding, causing weight loss, blemishes, and lower egg production.The Tick is specially difficult to control since it hides near the roots of birds during the day.At night, however, the nymps and adults climb onto the birds and engage themselves with blood.

\section{Echidonophaga gallinacean}

The Stick tight Flea can be severe poultry pest in Florida. Symptoms of infestations are dark-brown spots on the face, comb, and wattle where the fleas are embedded in the skin. Young fowl can be killed and other fowl may reduce egg production as a result of the irritation and blood loss. 


\section{Results \&Discussion}

During the study in all 82 chicks were examined, out of which 58 were infected and 24 were uninfected. The percent of infection was found to be $70.73 \%$. Out of 58 infected birds, 31\%exhibited single infection, $44.82 \%$ showed double infection and $24.13 \%$ were with triple infection. One of them was found infected with more than three ectoparasites. In all 10 different types of ectoparasites were found harboring broiler in Meerut. (Fig.1 \& 2)

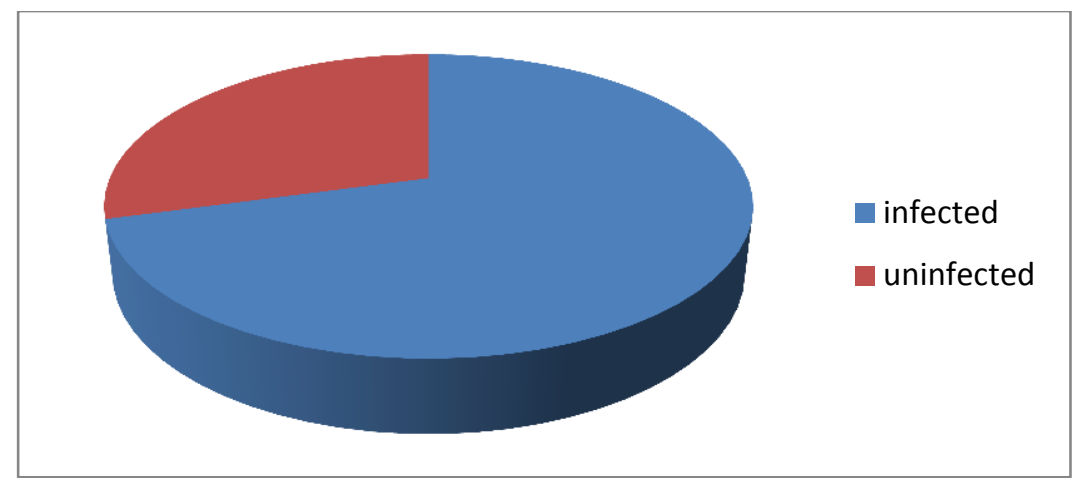

Fig.1. Percent of Ectoparasitic infection in Broiler Chicks in Meerut

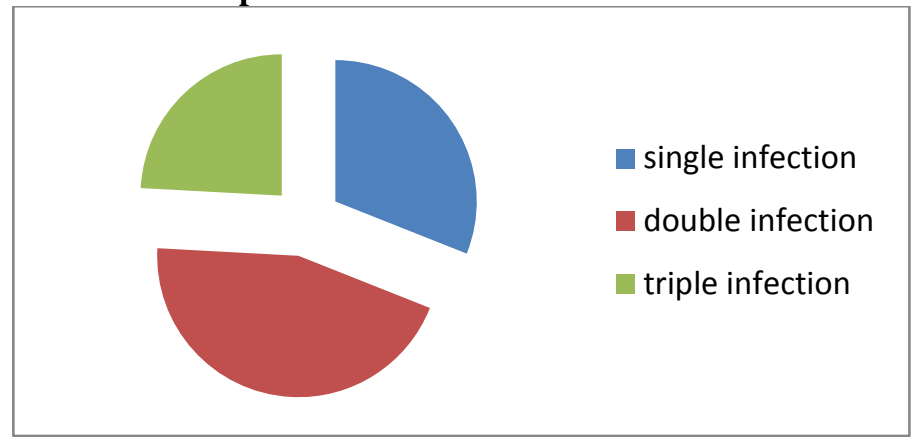

Fig.2. Types of infection in Broiler Chicks in Meerut

Parasite wise percent of infection was found to be Menacanthus stramineus 3\%, Menacanthus cornutus 14\%, Ligeurus lawrensis tropicalis $22 \%$, Goniocotes gallinae $15 \%$ and G.dissimilis $8 \%$. Poultry mites,(Ornithonyssus bursa and Dermanyssus gallinae)75. Fowl Tick,(Argas persicus)50\%, Sticktight Flea,(Echidnophaga gallinacean) $4 \%$. (Fig 3)

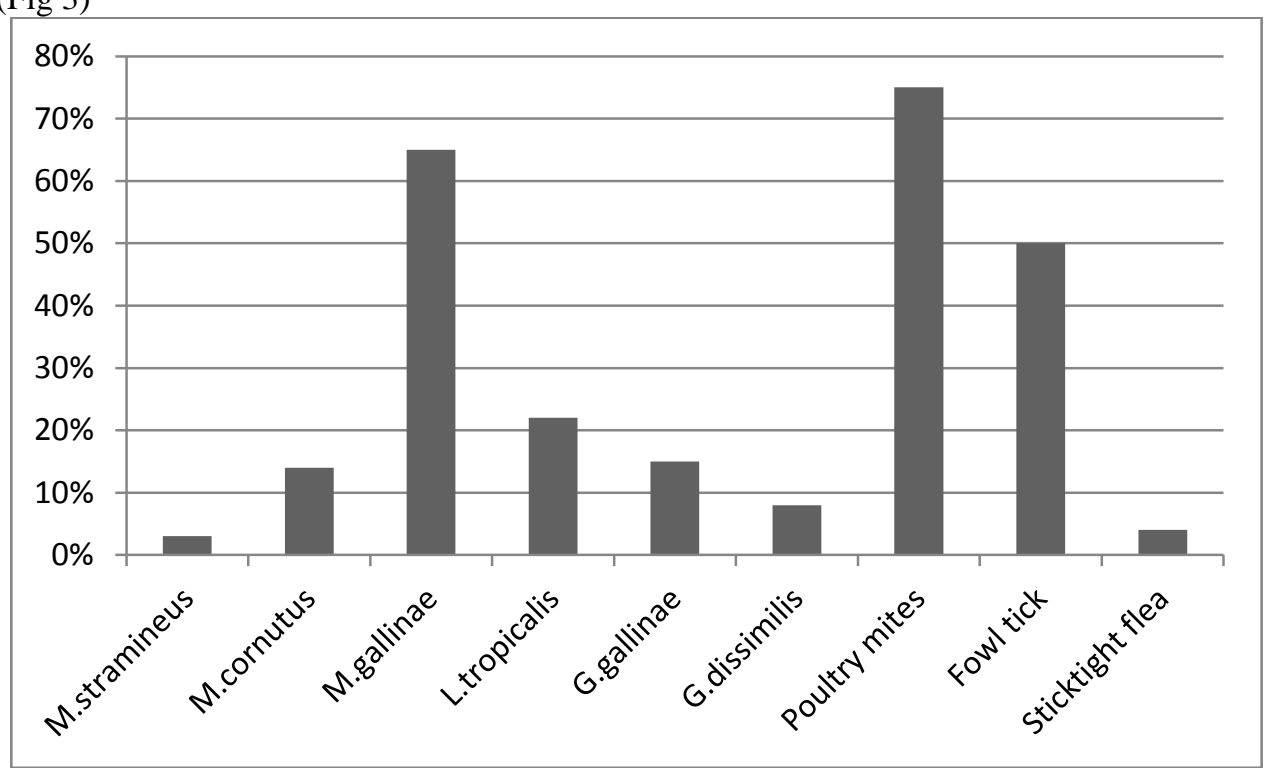

Fig 3. Species wise percent of infection in Broiler chicks in Meerut

\section{Conclusion}

The finding of the present investigation clearly reveals that in Indian broiler chicks specially in rural area are infected with ectoparasites, which are not only themselves a health problem but are serious threat to the avian stock being carrier of variety of disease. 


\section{References}

[1] Warren D.C, Eaton R and Smith H. 1948. Influence of infestation of body lice on egg production in the hen. Poult. Sci.,27:641-642.

[2] Edgar E.R and King D.F 1950. Effect of the body louse Eomenacanthusstramineus, on mature chickens.Poult.Sci.,29:214-219.

[3] Glees E.E. and Raun E.S 1959.Effect of chicken body louse infestation on egg production. J. Eco.Ent.,52:358-359.

[4] Stockdale H.J. and Raun E.S. 1960.Economic importance of the chicken body louse. J.Econ. Entomol.,53:421-432.

[5] Deryo A.1968.Investigation on economic disadvantage of Mallophaga VI. An influence of ecological and physiological factors on the intensity of Mallophaga infestation. Przegl.Zool.,19:181-187.

[6] Deryo A. 1974.Studies on economic harmfulness of Mallophaga I. The influence of lice infestation on egg laying and hatching in hens.Medycyna Vet., 30:406-410.

[7] Deryo A. 1974. Studies on the economic harmfulness of MallophagaII.The influence of Mallophagian invasion on the health in state of hens and turkeys. Medycyna Vet.,30:353-357.

[8] De Vaney J.A. 1976. Effects of the chicken body louse, Menacanthusstramineus on caged layers.Poultry Sci.,55:430-435.

[9] Pavlovic I, BlazinV.Hundina V, Ilic Z. and Miljkovic B. 1988. Effect of the louse Cuclogasterheterographus on reducing the laying capacity of fowl under intensive condition. Veterina. Glas.,42:637-642.

[10] PavlovicI,Blazin V, Hundina V, Ilic Z and Miljkovic B. 1989. Effect of the biting louse Menacanthusstramineus on reducing the egg production of poultry under intensive condition.Veterina. Glas.,43:181-186.

[11] Lehmann T.1993. Ectoparasites: direct impact on host fitness. Parasitology Today.,9:8-13.

[12] Islam M.K, Mondal M.M.H, Rehman M.M., Haque A.K.M.F and Chaudhary M.A.A. 1999. Effect of Lipeuruscaponis Linnaeus, 1958 (Mallophaga: Philopteridae) on laying hens. Vet.Rev.,14:32-33.

[13] Olitsky P.K. and Casal J.1959. Arthropods born group:A virus infection of man. In Viral and rickettisal infections of man (3 ${ }^{\text {rd }}$ ed.), Rivers and Horsfalleds.

[14] Eddie B, Meyer K.F,Lambrecht F.L. and Furman D.P. 1962. Isolation of Ornithosisbedsoniae from mites collected in Turkey quarters and from chicken lice. J. Infect.Diseases.,110:231-237.

[15] Deryo, A.1969. Mallophaga as vectors of Pasteurellamultocida. Ann. Univ. Mariac Curie.,24:355-366.

[16] Deryo A.1970. Mallophaga as resevior of Pasteurellamultocida. Acta.Parasitol.Polon.,17:113-119.

[17] Deryo A.1972. Aktualnustan, badania and rolaepizootiogicznaWszolow (mallophaga). Wiad. Parazytol.,18:531-533.

[18] Deryo A.1975. Badania and Szkodliwosciagospodarczawszolow V.ProbaustaleniaroliwszolowEomenacanthusstramineus (Nitzsch).W PrezenoszeniutyFusu u Kur.Wiad. Parazytol.,21:61-68.

[19] Deryo A. and Jarosz J.1972. Mikroflorajelitowaniektorychwszolowhaematogagiczynch. Wiad.Parazytol.,8:113-199.

[20] Pennington N.E.and Phelps C.A.1969. Canninefilariasis on Okinawa, Ryukyu Island.J.Med. Entomol.,60:59-67.

[21] Seager S.W, Schiller E.L, Staden W.J.L and Trpis M. 1976. A MallophagaTrinotonanserinum, as a cyclodevelopmental vector for a heartworm parasiter of a waterfowl.Science, 194:739-741.

[22] Barlett C.M and Anderson R.C. 1987.Pelecitusfulicaeatrae (Nematoda:Filariodea) of coots (Griformes) and grebes (Podicipediformes): Skin-inhabiting microfilariae and development in Mallophaga.Can.J.Zool., 65:2803-2812.

[23] Barlett C.M and Anderson R.C. 1989. Some observation of Pseudomenoponpilosum (Amblycera: Menoponidae), the louse vector of Pelecitusfulicaeatrae (Nematoda: Filariodea) of coots, Fuliaamerican .A. 1991. The louse (Avea: Gruiformes). Can. J. Zool., 67:1328-1331.

[24] Cohen S, Greenwood M.T and Fowler J.A 1991.The louse, Trinotonanseruinum (Amblycera:Phthiraptera) an intermediate host of Sarconemaeuryceca (Filoriodea: Nematoda), a heart worm of Swans. Med.Vet. Entomol., 5:101-110.

[25] Wilson F.H.1934. The life cycle and bionomics of Lipeurusheterographus (Nitzsch ).J.Parasitol., 20:304-311.

[26] Wilson F.H 1939. The lifecycle and bionomics of Lipeuruscaponis Linn.Annals Entomol.Soc.America.,32:318-320.

[27] Arora G.L. and Chopra N.P. 1959. Observation on the life history of Lipeurustropicalis peters (Mallophaga: Ischnocera). Res. Bull.Punjab Univ., 10:179-187.

[28] Stockdale H.J. and Raun E.S. 1965.Biology of the chicken body louse, Menacanthusstramineus.Ann.Entomol.,Soc.Amer., 58:802805 .

[29] Ahmad J.1986. Use of pestoban for the control of lice in poultry.Int. J. Indigenous Med. 5:11-13.

[30] Saxena A.K, Trivedi M.C, Rawat B.S and Kumar A. 1991. Bionomics of poultry louse, Lipeuruslawrensistropicalis peters (Phthiraptera: Ischnocera). J. zoal.Res., 4:27-32.

[31] SurmanSingh S.K, Saxena A.K. and Kumar A. 1998. Aspects of oviposition in the poultry shaft louse, Menopongallinae (Phthiraptera: Amblycera). J.Zool.Res., 4:37-42.

[32] Rafiq N.Z. 2000. Taxonomy and effect of ectoparasies on the egg production and blood parameters of White Leghorn and indigenous layes. M.Sc. Thesis, College of Veterinary Science, Lahore.

[33] Singh S.K, Surman Kumar S, Badola S and Saxena A.K. 2000. Site preference of four pigeon lice (Phthiraptera: Insecta) on the host body. Rivista di Parasitol., XVII :341-343.

[34] Kumar S. 2002. Selected asspects of population ecology oviposition and eradication of phthirapteranectoparasites infesting poultry bird, Gallus gallusdomesticus.Ph.D. Thesis,H.N.B.University,Srinagar.

[35] Goel S, Rastogi R and Singh H.S. 20005. Prevalance, intensity and rate of infestation of phthirapteran parasites on poultry bird, Gallus gallusdomesticusin Meerut region.Uttar Pradesh J.Zool., 25:157-162.

[36] Linne. 1758. (Aves, Passeriformes, Muscicapidae, Turdinae). Revista de la SociedadEntomologicaArgentina. 44:91-102.

[37] Peters H.S. 1931. A new louse from domestic chickens (Mallophaga: Philopteridae).Entomological News.42:195-199.

[38] De Geer C.1778. Memories pour servira I historienaturella des insects apteres. Des poux.7:62-68.

[39] Denny H.1842. MonographiaanoplurorumBritanniae or an Essay on the Brtish Species of ParasiticInsects. Henry G.Bohn, London. xxvi+262. 